\title{
Biological Activity of Halogen-Containing Derivatives of $N$-Substituited Quinone Imines
}

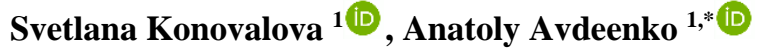 \\ 1 Chemistry Department, Donbas State Engineering Academy, Akademichna Str., 72, Kramatorsk, 84313, Ukraine \\ * Correspondence: chimist@dgma.donetsk.ua;
}

Received: 10.05.2020; Revised: 2.06.2020; Accepted: 2.06.2020; Published: 6.06.2020

\begin{abstract}
The different halogen-containing derivatives of $N$-substituted quinone imines have been synthesized by the halogenation and hydrohalogenation of the corresponding quinone imines. $N, N^{\prime}-$ (Cyclohexa-2-en-1,4-diylidene)-diarylsulfonamides are good insecticides. They cause $89-97 \%$ of the insects to die. Compared with quinone imine, compounds having 4-oxocyclohexa-2,5-en-1-ylidene structure show higher fungicidal activity. $N$-(3,5-Dichloro-4-oxocyclohexa-2,5-dien-1-ylidene)-4methylbenzene-1-sulfonamide and 4-chloro- $N$-[2,3,5,5,6,6-hexachloro-4-oxocyclohexa-2-en-1ylidene]benzene-1-sulfonamide inhibit the growth and development of Phytophthora infestans by 82 and $81 \%$, respectively. $N$-[2,3,5,5,6,6-Hexachloro-4-oxocyclohexa-2-en-1-ylidene]-4-methylbenzene1 -sulfonamide has a high herbicidal activity. The compounds with the largest number of chlorine atoms have the highest insecticidal, fungicidal, and herbicidal activity.
\end{abstract}

Keywords: quinone; quinone imine; 4-oxocyclohexa-2,5-dien-1-ylidene; halogen derivatives; hydrohalogenation; halogenation; herbicide; insecticide; fungicide.

(c) 2020 by the authors. This article is an open-access article distributed under the terms and conditions of the Creative Commons Attribution (CC BY) license (https://creativecommons.org/licenses/by/4.0/).

\section{Introduction}

Quinone imines and their derivatives containing the structure of 4-iminocyclohexa-2,5diene-1,4-one are representatives of a large family of quinoid compounds. They exist in natural products $[1,2]$, endogenous biochemical substances [3,4], drugs [5, 6], and environmental objects $[7,8]$.

Natural quinones perform many functions in biological systems. Their most important role is in the electron transfer in metabolic processes such as photosynthesis and respiration in humans [9].

When using drugs, natural products, and environmental chemicals, the formation of quinone compounds is essential to human life. Quinones can cause a variety of harmful effects and can also have beneficial physiological effects [4].

On the one hand, quinone imines are highly active metabolites, which can cause dangerous effects [10-13]. They are responsible for cytotoxicity [12, 14, 15], immunotoxicity $[12,16]$, and carcinogenesis $[12,14,16]$.

On the other hand, they can be antimalarial drugs [6], cytoprotective agents [17], can exhibit anti-inflammatory [17] and antioxidant [2, 3, 5] activity, causing changes in the redox state [17]. Some quinone methides and quinone imines have anticancer activity [18,19], and quinone imine sulfonamides exhibit antibacterial activity [20]. 
Halogen-containing quinoid compounds show hepatotoxicity [10, 21], carcinogenicity [22], and can be used as anticancer drugs [23]. They are widely used as pesticides [8, 24, 25].

Various halogen-containing derivatives of quinone imines have been previously synthesized [26-29], but their biological activity has not been investigated. The purpose of this work is to study the biological activity of quinone imine derivatives containing halogen atoms.

\section{Materials and Methods}

\subsection{General experimental details.}

The ${ }^{1} \mathrm{H}$ NMR spectra were obtained on a Varian VXR-300 spectrometer, $300 \mathrm{MHz}$. TMS was an internal standard. $\mathrm{CDCl}_{3}$ was used as a solvent. The purity of the halogen derivatives of quinone imines was determined by TLC using Silufol UV-254 plates. Acetone was a solvent. A mixture of benzene and hexane, 10:1, was used as eluent. The spots on the plate were developed under UV light. All melting points were uncorrected.

$\mathrm{N}$-(4-Oxocyclohexa-2,5-dien-1-ylidene)arylsulfonamides $1-4, \quad \mathrm{~N}$-[4-oxocyclohex-2en-1-ylidene]arylsulfonamides $\quad 5, \quad 6, \quad N$-[4-oxo-3,4-dihydronaphthalen-1(2H)-ylidene]arylsulfonamides 12,13 , and $N, N$ '-(cyclohex-2-en-1,4-diylidene)-diarylsulfonamides 17-19, 33,34 were synthesized by halogenation of the corresponding quinone imines by procedure $[26,27]$.

$N$-[4-Oxonaphthalen-1(4H)-ylidene]arylsulfonamides 7-11, 29-31, N,N'-(cyclohexa2,5-diene-1,4-diylidene)diarylsulfonamides $14-16,32$, and $N$-(4-oxocyclohexa-2,5-dien-1ylidene)arylsulfonamides 20-28 were synthesized by hydrohalogenation of the quinone imines by procedure [28].

The characteristics of all compounds synthesized in this work correspond to literary data [29].

\subsection{Biological studies.}

The study of the biological activities of halogen derivatives of quinone imines was carried out in the laboratory of protective-stimulating products of the Kyiv environmental protection company "Creoma”, Ukraine.

\section{Results and Discussion}

The compounds 1-34 (scheme 1) were studied for insecticidal activity against Musca domestica (house flies), Sitophilus oryzae (rice weevils), Tetranychus urticae (spider mites), and Aphis fabae Scopoli (black beet aphids). The concentration of the compound in the test solution was $0.5 \%$. In the tests for the anti-nematode activity against galls forming on cucumber roots, the concentration of the compound applied to the soil was $80 \mathrm{mg} / \mathrm{kg}$.

House flies (Musca domestica) are ubiquitous flies usually found on decaying garbage, feces, and human food. They are very harmful because they carry microorganisms, including pathogens [30]. Rice weevil (Sitophilus oryzae) is the main pest of grains stored in the subtropics and tropics [31]. The spider mite (Tetranychus urticae) is one of the most widespread omnivorous herbivores, feeding on more than 1,000 plants, causing economic losses to both ornamental and agricultural plants [32]. The black beet aphids (Aphis fabae Scopoli) are one of the more significant menaces to forests and agriculture [33]. 
<smiles>[X]C1=C([Y])C(=N[S+](=O)[O-])C=C(Cl)C1=O</smiles>
1: $\mathrm{X}=\mathrm{Y}=\mathrm{H}, 2: \mathrm{X}=\mathrm{Cl}, \mathrm{Y}=\mathrm{H}$,
3: $\mathrm{X}=\mathrm{Y}=\mathrm{Cl}, \mathbf{4}: \mathrm{X}=\mathrm{H}, \mathrm{Y}=\mathrm{Cl}$<smiles></smiles>

12: $\mathrm{R}=\mathrm{Me}, 13: \mathrm{R}=\mathrm{H}$<smiles>[R]c1ccccc1</smiles>

5: $\mathrm{R}=\mathrm{Me}, 6: \mathrm{R}=\mathrm{C}$<smiles></smiles>

14: $\mathrm{Y}=\mathrm{X}=\mathrm{H}$,

15: $\mathrm{Y}=\mathrm{Cl}, \mathrm{X}=\mathrm{H}$

16: $\mathrm{Y}=\mathrm{X}=\mathrm{Cl}$.
7: $\mathrm{X}=\mathrm{Y}=\mathrm{H}, \mathrm{R}=\mathrm{Cl}$,

8: $\mathrm{X}=\mathrm{Cl}, \mathrm{Y}=\mathrm{H}, \mathrm{R}=\mathrm{M}$

9: $\mathrm{X}=\mathrm{Cl}, \mathrm{Y}=\mathrm{H}, \mathrm{R}=\mathrm{Cl}$,

10: $\mathrm{X}=\mathrm{Y}=\mathrm{Cl}, \mathrm{R}=\mathrm{Me}$,

11: $\mathrm{X}=\mathrm{Y}=\mathrm{Cl}, \mathrm{R}=\mathrm{H}$

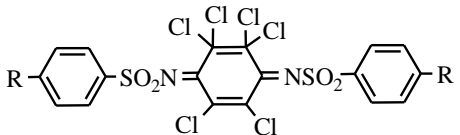

17: $\mathrm{R}=\mathrm{Me}, 18: \mathrm{R}=\mathrm{Cl}, 19: \mathrm{R}=\mathrm{H}$.

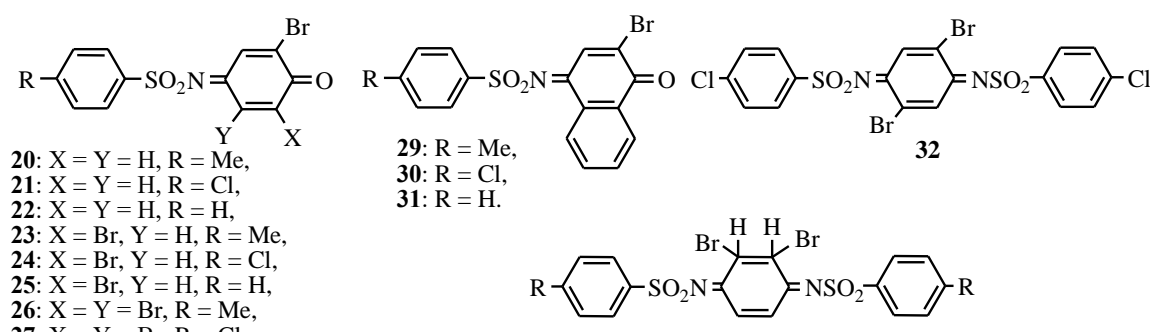

26: $\mathrm{X}=\mathrm{Y}=\mathrm{Br}, \mathrm{R}=\mathrm{Me}$,

27. $\mathrm{X}=\mathrm{Y}=\mathrm{Br}, \mathrm{R}=\mathrm{Cl}$,

33: $\mathrm{R}=\mathrm{Me}$, 34: $\mathrm{R}=\mathrm{H}$.

Scheme 1. The halogen derivatives of quinone imines.

The results of the tests for insecticidal and anti-nematode activities of compounds 1-34 are shown in Table 1.

Table 1. The test results of anti-nematode and insecticidal activities of compounds 1-34.

\begin{tabular}{|c|c|c|c|c|c|}
\hline \multirow[b]{2}{*}{$\begin{array}{l}\text { Compound } \\
\text { number }\end{array}$} & \multicolumn{4}{|c|}{ The death index of insects and mites, \% } & \multirow{2}{*}{$\begin{array}{l}\text { The reduction of gall } \\
\text { formation on } \\
\text { cucumber roots, } \%\end{array}$} \\
\hline & House flies & Rice weevils & Spider mites & $\begin{array}{ll}\text { Black } & \text { beet } \\
\text { aphids } & \\
\end{array}$ & \\
\hline 1 & 53 & 38 & 0 & 4 & 18 \\
\hline 2 & 3 & 24 & 44 & 0 & 9 \\
\hline 3 & 14 & 5 & 36 & 0 & 3 \\
\hline 4 & 0 & 68 & 14 & 6 & 0 \\
\hline 5 & 14 & 11 & 61 & 8 & 0 \\
\hline 6 & 2 & 14 & 42 & 7 & 0 \\
\hline 7 & 0 & 15 & 5 & 16 & 0 \\
\hline 8 & 0 & 56 & 0 & 10 & 0 \\
\hline 9 & 11 & 22 & 62 & 0 & 37 \\
\hline 10 & 0 & 65 & 16 & 0 & 0 \\
\hline 11 & 8 & 43 & 51 & 0 & 0 \\
\hline 12 & 0 & 14 & 0 & 0 & 0 \\
\hline 13 & 16 & 24 & 66 & 0 & 20 \\
\hline 14 & 5 & 13 & 0 & 7 & 0 \\
\hline 15 & 0 & 24 & 10 & 10 & 0 \\
\hline 16 & 3 & 38 & 26 & 12 & 0 \\
\hline 17 & 0 & 91 & 72 & 3 & 0 \\
\hline 18 & 2 & 97 & 69 & 3 & 31 \\
\hline 19 & 4 & 46 & 0 & 0 & 0 \\
\hline 20 & 0 & 3 & 0 & 4 & 47 \\
\hline 21 & 0 & 5 & 0 & 0 & 66 \\
\hline 22 & 0 & 0 & 0 & 0 & 25 \\
\hline 23 & 0 & 0 & 0 & 0 & 46 \\
\hline 24 & 5 & 5 & 15 & 0 & 39 \\
\hline 25 & 5 & 8 & 0 & 0 & 46 \\
\hline 26 & 5 & 5 & 0 & 0 & 0 \\
\hline 27 & 5 & 8 & 0 & 0 & 0 \\
\hline 28 & 16 & 3 & 0 & 0 & 0 \\
\hline 29 & 89 & 76 & 0 & 0 & 50 \\
\hline 30 & 0 & 3 & 0 & 0 & 0 \\
\hline 31 & 0 & 0 & 0 & 0 & 0 \\
\hline 32 & 0 & 0 & 12 & 11 & 0 \\
\hline 33 & 0 & 6 & 1 & 8 & 0 \\
\hline 34 & 0 & 14 & 11 & 0 & 0 \\
\hline
\end{tabular}


Compounds 17 and 18 showed good results. The death index was $91 \%$ and $97 \%$ at the action on rice weevils and $72 \%$ and $69 \%$ for spider mites. It should be noted that compound 18 has the maximum number of chlorine atoms in composition.

Table 2. The results of the test for the fungicidal activity of compounds 1-34.

\begin{tabular}{|c|c|c|c|c|c|c|c|c|}
\hline \multirow{3}{*}{$\begin{array}{l}\text { Compound } \\
\text { number }\end{array}$} & \multicolumn{5}{|c|}{ Colonies of bacteria and fungi, concentration of $0.003 \%$} & & & \\
\hline & \multirow{2}{*}{$\begin{array}{l}\text { Xanthomonas } \\
\text { malvacearum }\end{array}$} & \multirow{2}{*}{$\begin{array}{l}\text { Fusarium } \\
\text { moniliforme }\end{array}$} & \multirow{2}{*}{$\begin{array}{l}\text { Penicillium } \\
\text { cyclopium }\end{array}$} & \multirow{2}{*}{$\begin{array}{l}\text { Venturia } \\
\text { Inaegualis }\end{array}$} & \multirow{2}{*}{$\begin{array}{l}\text { Aspergillius } \\
\text { niger }\end{array}$} & \multicolumn{2}{|c|}{$\begin{array}{l}\text { Concentration } \\
\text { of } 0.1 \%\end{array}$} & \multirow{2}{*}{$\begin{array}{l}\text { Concentration } \\
\text { of } \mathbf{0 . 0 5 \%} \\
\begin{array}{l}\text { Oidium } \\
\text { erysiphoides }\end{array}\end{array}$} \\
\hline & & & & & & $\begin{array}{l}\text { Phytophthora } \\
\text { infestans }\end{array}$ & $\begin{array}{l}\text { Botrytis } \\
\text { cinerea }\end{array}$ & \\
\hline 1 & 14 & 18 & 17 & 22 & 0 & 0 & 0 & 0 \\
\hline 2 & 21 & 31 & 0 & 16 & 13 & 82 & 62 & 0 \\
\hline 3 & 21 & 31 & 0 & 27 & 36 & 0 & 29 & 0 \\
\hline 4 & 6 & 27 & 0 & 29 & 17 & 40 & 0 & 0 \\
\hline 5 & 14 & 25 & 0 & 27 & 13 & 0 & 0 & $\begin{array}{l}\text { herbicide } \\
\text { effect }\end{array}$ \\
\hline 6 & 0 & 0 & 0 & 0 & 20 & 81 & 53 & 41 \\
\hline 7 & 13 & 8 & 0 & 21 & 0 & 0 & 0 & 30 \\
\hline 8 & 0 & 29 & 0 & 0 & 27 & 0 & 54 & 0 \\
\hline 9 & 20 & 18 & 0 & 5 & 29 & 0 & 63 & 0 \\
\hline 10 & 14 & 22 & 27 & 0 & 0 & 37 & 58 & 66 \\
\hline 11 & 29 & 13 & 0 & 26 & 0 & 71 & 23 & 56 \\
\hline 12 & 20 & 70 & 37 & 41 & 41 & 0 & 0 & 60 \\
\hline 13 & 29 & 51 & 23 & 42 & 39 & 22 & 4 & 61 \\
\hline 14 & 0 & 0 & 0 & 0 & 20 & 0 & 0 & 78 \\
\hline 15 & 0 & 0 & 0 & 0 & 0 & 60 & 0 & 45 \\
\hline 16 & 28 & 27 & 0 & 27 & 13 & 0 & 0 & 0 \\
\hline 17 & 14 & 2 & 11 & 5 & 11 & 0 & 0 & 19 \\
\hline 18 & 0 & 34 & 0 & 16 & 7 & 69 & 0 & 53 \\
\hline 19 & 43 & 20 & 27 & 11 & 0 & 0 & 0 & 0 \\
\hline 20 & 14 & 33 & 0 & 31 & 17 & 0 & 42 & 0 \\
\hline 21 & 14 & 7 & 0 & 36 & 29 & 0 & 0 & 0 \\
\hline 22 & 0 & 26 & 0 & 27 & 0 & 0 & 0 & 0 \\
\hline 23 & 14 & 45 & 12 & 50 & 23 & 0 & 24 & 0 \\
\hline 24 & 28 & 28 & 18 & 40 & 0 & 59 & 14 & 0 \\
\hline 25 & 21 & 16 & 18 & 31 & 23 & 0 & 62 & 0 \\
\hline 26 & 28 & 9 & 12 & 27 & 23 & 13 & 20 & 0 \\
\hline 27 & 14 & 33 & 0 & 40 & 5 & 0 & 0 & 0 \\
\hline 28 & 0 & 33 & 31 & 50 & 0 & 0 & 0 & 0 \\
\hline 29 & 21 & 40 & 0 & 45 & 0 & 21 & 0 & 0 \\
\hline 30 & 7 & 14 & 0 & 40 & 5 & 0 & 52 & 0 \\
\hline 31 & 21 & 33 & 12 & 18 & 0 & 0 & 25 & 0 \\
\hline 32 & 37 & 11 & 0 & 13 & 0 & 0 & 0 & 0 \\
\hline 33 & 50 & 79 & 68 & 62 & 69 & 0 & 0 & 0 \\
\hline 34 & 42 & 73 & 56 & 75 & 70 & 0 & 0 & 0 \\
\hline
\end{tabular}

Among the bromine-containing derivatives, compound 29 was the most active. It caused $89 \%$ of the houseflies and $76 \%$ of rice weevil to die. Other compounds showed a relatively low insecticidal activity.

Under the action of compound 21, the maximum reduction of gall formation on cucumber roots was $66 \%$. Compared with other compounds, the bromine-containing $\mathrm{N}$-(4oxocyclohexa-2,5-dien-1-ylidene)-arylsulfonamides 20-25 had a higher anti-nematode activity. But the activity of the remaining compounds against galls forming on cucumber roots was either very low or equal zero.

To study the bactericidal activity of the compounds 1-34, we investigated their action on eight objects: Fusarium moniliforme, Penicillium cyclopium, Aspergillus niger, Venturia Inaequalis, Xanthomonas malvacearum, Botrytis cinerea, Oidium erysiphoides, Phytophthora infestans. Xanthomonas malvacearum causes blackarm. Penicillium cyclopium affects cereal products and grains. Venturia inaequalis causes the apple scab disease. Fusarium moniliforme indices corn stalk and ear rot. Aspergillus niger causes aspergillosis in human and animals. The responses of four types of fungi, Penicillium cyclopium, Venturia Inaequalis, Aspergillus niger, and Fusarium moniliforme were tested on a solid medium. The effects of the tested 
compounds on Botrytis cinerea, Oidium erysiphoides, and Phytophthora infestans were studied on green plants. The test results of the activity of the compounds 1-34 are shown in Table 2 .

Compounds $12,13,23,28,33$, and 34 showed relatively high fungicidal activity against fungi when tested on a solid medium. Compounds 2 and 6 showed significant fungicidal activity against Phytophthora infestans, inhibiting the development of the disease by 82 and $81 \%$, respectively. Inhibition of the growth and development of diseases of the green plant diseases was $50-70 \%$ when using compounds $8-15,18,24,25,30$.

Thus, the compounds having a 4-oxocyclohex-2-en-1-ylidene structure and compounds having a quinone imine ring had fungicidal activity. Although 4-oxocyclohex-2-en-1-ylidene structures are more active than quinoid compounds (see Table 2).

The herbicidal activity of compounds 1-34 was also tested. The studies were carried out on wheat, sorghum, oats, buckwheat, and radish. The concentration of the tested compound was equal to $5 \mathrm{~kg}$ per hectare. The tests were performed in two ways. The first method was to spray the soil before sowing. Moreover, the second was to spray the vegetative half of the plants. Of all the compounds studied, only aryl sulfonamide 5 showed a high herbicidal effect.

\section{Conclusions}

$N, N^{\prime}$-(Cyclohex-2-ene-1,4-diylidene)-diarylsulfonamides are good insecticides. They cause $89-97 \%$ of the insects to die. The compounds are having a 4-oxocyclohex-2-en-1-ylidene structure show higher fungicidal activity than quinone imines. $N$-(3,5-Dichloro-4oxocyclohexa-2,5-dien-1-ylidene)-4-methylbenzene-1-sulfonamide and 4-chloro- $N$ [2,3,5,5,6,6-hexachloro-4-oxocyclohex-2-en-1-ylidene]benzene-1-sulfonamide inhibit the growth and development of Phytophthora infestans by 82 and $81 \%$, respectively. $\mathrm{N}$ [2,3,5,5,6,6-Hexachloro-4-oxocyclohex-2-en-1-ylidene]-4-methylbenzene-1-sulfonamide has a high herbicidal activity. The compounds with the largest number of chlorine atoms have the highest insecticidal, fungicidal, and herbicidal activity.

\section{Funding}

This research received no external funding.

\section{Acknowledgments}

This research has no acknowledgment.

\section{Conflicts of Interest}

The authors declare no conflict of interest.

\section{References}

1. Pavarini, D.P.; Selegato, D.M.; Castro-Gamboa, I.; do Sacramento, L.V.S.; Furlan, M. ecological insights to track cytotoxic compounds among Maytenus ilicifolia living individuals and clones of an ex situ collection. Molecules 2019, 24, https://doi.org/10.3390/molecules24061160.

2. Sajjad, N.; Wani, A.; Hassan, S.; Ali, R.; Hamid, R.; Akbar, S.; Ganai, B.; Bhat, E. Interplay of antioxidants in Alzheimer's disease. Journal of Translational Science 2019, 5, 1-11.

3. Atia, A.; Alrawaiq, N.; Abdullah, A.A Review of NAD(P)H:Quinone oxidoreductase 1 (NQO1); a multifunctional antioxidant enzyme. Journal of Applied Pharmaceutical Science 2014, 4, 118-122, https://doi.org/10.7324/JAPS.2014.41220. 
4. Kato, Y.; Suga, N. Covalent adduction of endogenous and food-derived quinones to a protein: its biological significance. Journal of Clinical Biochemistry and Nutrition 2018, 62, 213-220, https://doi.org/10.3164/jcbn.18-26.

5. Li, X.; Zhan, J.; Hou, Y.; Hou, Y.; Chen, S.; Luo, D.; Luan, J.; Wang, L.; Lin, D. Coenzyme Q10 regulation of apoptosis and oxidative stress in $\mathrm{H}_{2} \mathrm{O}_{2}$ induced BMSC death by modulating the Nrf-2/NQO-1 signaling pathway and its application in a model of spinal cord injury. Oxidative Medicine and Cellular Longevity 2019, 2019.

6. Ghavami, M. Antimalarial agents: new mechanisms of actions for old and new drugs. PhD Thesis in Chemistry, Virginia Polytechnic Institute and State University, Blacksburg, VA, USA, June 1st 2018.

7. Hsueh, C.C.; Wu, C.C.; Chen, B.Y. Polyphenolic compounds as electron shuttles for sustainable energy utilization. Biotechnology for Biofuels 2019, 12, https://doi.org/10.1186/s13068-019-1602-9.

8. Clark, R.D. Predicting mammalian metabolism and toxicity of pesticides in silico. Pest Management Science 2018, 74, 1992-2003, https://doi.org/10.1002/ps.4935.

9. Tariq, M.; Ullah, I. Electrochemical behavior of 1,2-dihydroxyanthraquinone dianion in aprotic solventsDMSO and DMF: understanding the hydrogen bonding phenomena and protonation effect in biochemical systems. SN Applied Sciences 2020, 2, https://doi.org/10.1007/s42452-020-2707-2.

10. Ramesh, M.; Bharatam, P.V. Formation of a toxic quinoneimine metabolite from diclofenac: a quantum chemical study. Drug Metabolism Letters 2019, 13, 64-76, https://doi.org/10.2174/1872312812666180913120736.

11. Gawlik, M.; Skibiński, R.; Trawiński, J.; Komsta Ł. Photocatalysis combined with chromatographic methods as a new promising tool in drug metabolism studies - a review. Acta Chromatographica 2018, 30, 1-8, https://doi.org/10.1556/1326.2016.00202.

12. Klopčič, I.; Dolenc, M.S. Chemicals and Drugs Forming Reactive Quinone and Quinone Imine Metabolites. Chemical Research in Toxicology 2019, 32, 1-34, https://doi.org/10.1021/acs.chemrestox.8b00213.

13. Winkler, M.; Geier, M.; Hanlon, S.P.; Nidetzky, B.; Glieder, A. Human enzymes for organic synthesis. Angew. Chem. Int. Ed. 2018, 57, 13406-13423, https://doi.org/10.1002/anie.201800678.

14. Lin, P.Y.; Chang, Y.J.; Chen, Y.C.; Lin, C.H.; Erkekoglu, P.; Chao, M.W.; Tseng, C.Y. Anticancer effects of 3,5-dimethylaminophenol in A549 lung cancer cells. PLoS ONE 2018, 13, https://doi.org/10.1371/journal.pone.0205249.

15. Lazarska, K.E.; Dekker, S.J.; Vermeulen, N.P.E.; Commandeur, J.N.M. Effect of UGT2B7*2 and CYP2C8*4 polymorphisms on diclofenac metabolism. Toxicology Letters 2018, 284, 70-78, https://doi.org/10.1016/j.toxlet.2017.11.038.

16. Claesson, A.; Minidis, A. Systematic approach to organizing structural alerts for reactive metabolite formation from potential drugs. Chemical Researcg in Toxicology 2018, 31, 389-411, https://doi.org/10.1021/acs.chemrestox.8b00046.

17. Bolton, J.L.; Dunlap, T. Formation and biological targets of quinones: cytotoxic versus cytoprotective effects. Chemical Researcg in Toxicology 2017, 30,13-37, https://doi.org/10.1021/acs.chemrestox.6b00256.

18. Goermen, M.; Pigeon, P.; Top, S.; Hillard, E.A.; Huché, M.; Hartinger, C.G.; Montigny, F.; Plamont, M.A.; Vessières, A.; Jaouen, G. Synthesis, cytotoxicity, and compare analysis of ferrocene and [3]ferrocenophane tetrasubstituted olefin derivatives against human cancer cells. ChemMedChem 2010, 5, 2039-2050, https://doi.org/10.1002/cmdc.201000286.

19. Karakaş, D.; Akar, R.O.; Gökmen, Z.; Deniz, N.G.; Ulukaya, E. A novel 1,4-naphthoquinone-derived compound induces apoptotic cell death in breast cancer cells. Turkish Journal of Biology 2019, 43, 256-263, https://doi.org/doi:10.3906/biy-1901-19.

20. Mokhtari, B.; Nematollahi, D.; Salehzadeh, H. A tunable pair electrochemical strategy for the synthesis of new benzenesulfonamide derivatives. Scientific Repjrts 2019, 9, https://doi.org/10.1038/s41598-019-385444.

21. Aithal, G.P.; Björnsson, E.S.; Kaplowitz, N.; Kullak-Ublick, G.A.; Larrey, D.; EASL Clinical Practice Guidelines: Drug-induced liver injury. Journal of Hepatology 2019, 70, 1222-1261, https://doi.org/10.1016/j.jhep.2019.02.014.

22. Huang C.H., Ren F.R., Shan G.Q., Qin H., Mao L., Zhu B.Z. Molecular mechanism of metal-independent decomposition of organic hydroperoxides by halogenated quinoid carcinogens and the potential biological implications. Chemical Research in Toxicology 2015, 28, 831-837, https://doi.org/10.1021/tx500486z.

23. Rivera-Ávalos, E.; de Loera, D.; Araujo-Huitrado, J.G.; Escalante-García, I.L.; Muñoz-Sánchez, M.A.; Hernández, H.; López, J.A.; López, L. Synthesis of amino acid-naphthoquinones and in vitro studies on cervical and breast cell lines. Molecules 2019, 24, https://doi.org/10.3390/molecules24234285.

24. Avdeenko, A.P.; Konovalova, S.A. Quinone imines: from anticancer drugs to molecular computers: monograph. Donbas State Engineering Academy: Kramatorsk, Ukraine, 2018; pp. 238-388. (In Russian).

25. Kuz'menko, L.; Avdeenko, A.; Konovalova, S.; Vasylyuk, S.; Fedorova, O.; Monka, N.; Krychkovska, A.; Lubenets, V. Synthesis and study of pesticidal activity of some N-arylthio-1,4-benzoquinone imines. Biointerface Research in Applied Chemistry 2019, 9, 4232-4238, https://doi.org/10.33263/BRIAC95.232238. 
26. Avdeenko, A.P.; Konovalova, S.A.; Ludchenko, O.N. Halogenation of N-substituted para-quinone monoimine and para-quinone monooxime esters: VI. Regular trends in chlorination and bromination of Narylsulfonyl-1,4-benzoquinone monoimines alkyl-substituted in the quinoid ring. Russian Journal of Organic Chemistry 2006, 42, 683-688, https://doi.org/10.1134/S107042800605006X.

27. Avdeenko, A.P.; Konovalova, S.A.; Shishkina, S.V.; Omel'chenko, I.V. Activated sterically strained C=N bond in $N$-Substituted $p$-quinone mono- and diimines: XVII. Cyclohexene polyhalogen structures originating from $N$-(Arylsulfonyl)-p-quinone imines. Russian Journal of Organic Chemistry 2018, 54, 671-686, https://doi.org/10.1134/S1070428018050019.

28. Avdeenko, A.P.; Konovalova, S.A.; Ludchenko, O.N.; Ledeneva, O.P.; Vakulenko, A.V. Hydrohalogenation of N-acetyl(aroyl)-1,4-benzoquinone monoimines. Russian Journal of Organic Chemistry 2011, 47, 214 229, https://doi.org/10.1134/S1070428011020102.

29. Avdeenko, A.P.; Zhykova, S.A. Synthesis of polyhalogenated 2-cyclohene-1,4-dione derivatives containing hydrogen at the $s p^{3}$-carbon atoms from $N$-arylsulfonyl-p-quinonimines and N,N'-bis(arylsulfonyl)-pquinonediimines. Russian Journal of Organic Chemistry 1999, 35, 388-396.

30. Park, R.; Dzialo, M.C.; Spaepen, S.; Nsabimana, D.; Gielens, K.; Devriese, H.; Crauwels, S.; Tito, R.Y.; Raes, J.; Lievens, B.; Verstrepen, K.J. Microbial communities of the house fly Musca domestica vary with geographical location and habitat. Microbiome 2019, 7, https://doi.org/10.1186/s40168-019-0748-9.

31. Hong, K.J.; Lee, W.; Park, Y.J.; Yang, J.O. First confirmation of the distribution of rice weevil, Sitophilus oryzae, in South Korea. Journal of Asia-Pacific Biodiversity 2018, 11, 69-75, https://doi.org/10.1016/j.japb.2017.12.005.

32. Agut, B.; Pastor, V.; Jaques, J.A.; Flors, V. Can Plant Defence Mechanisms Provide New Approaches for the Sustainable Control of the Two-Spotted Spider Mite Tetranychus urticae? International Journal of Molecular Sciences 2018, 19, https://doi.org/10.3390/ijms19020614.

33. Saruhan, I. Efficacy of some entomopathogenic fungi against Aphis fabae Scopoli (Hemiptera: Aphididae). Egyptian Journal of Biological Pest Control 2018, 28, https://doi.org/10.1186/s41938-018-0096-2. 